\title{
Effect of PGRs on Quality and Yield Traits of Vegetable Cowpea [Vigna unguiculata (L.) Walp.]
}

\author{
J. P. Sarvaiya ${ }^{1 *}$, S. N. Saravaiya ${ }^{1}$, H. S. Patel ${ }^{1}$ and Y. N. Tandel ${ }^{2}$ \\ ${ }^{1}$ Department of Vegetable Science, ${ }^{2}$ Department of Fruit Science, ASPEE College of \\ Horticulture and Forestry, Navsari Agricultural University, India
}

*Corresponding author

Keywords

Cow pea, NAA, PCPA, 2,4-D, CCC, Quality and Yield

\section{Article Info}

Accepted:

15 June 2021

Available Online:

10 July 2021
A field experiment was carried out, at the Vegetable Research Farm, RHRS of the NAU, Navsari during Summer 2020 on cv. AVCP 1. The experiment was conducted in randomized block design (RBD) with three replications, which included 13 treatments. The results revealed that application of CCC $300 \mu \mathrm{l}^{-1}$ recorded higher values for quality and yield parameters namely, chlorophyll content of leaf at second $\left(1676.22 \mathrm{mg} 100 \mathrm{~g}^{-1}\right)$ and sixth picking $\left(1656.18 \mathrm{mg} 100 \mathrm{~g}^{-1}\right)$ and chlorophyll content of pod at second $(116.66 \mathrm{mg}$ $\left.100 \mathrm{~g}^{-1}\right)$ and sixth picking (116.34 mg $\left.100 \mathrm{~g}^{-1}\right)$, pod yield $\left(\mathrm{t} \mathrm{ha}^{-1}\right)(10.87$ tonne), marketable pod yield plant ${ }^{-1}(0.160 \mathrm{~kg})$ and marketable pod yield $(\mathrm{t}$ $\mathrm{ha}^{-1}$ ) (10.44 tonne), whereas protein content of immature seed (\%), moisture content of pod $(\%)$, crude fibre (\%), TSS $\left({ }^{\circ} \mathrm{B}\right)$, Harvest Index (\%) and number of pickings were found non-significant. From the economic point of view and based on green pod yield, for securing maximum return, foliar application of CCC $300 \mu \mathrm{l}^{-1}$ was found superior with highest B:CR value of 2.2 followed by $\mathrm{T}_{11}$ (B:CR value of 2.1 ).

\section{Introduction}

Amongst horticultural crops, vegetables have gained importance not only in providing better per unit returns but also in providing nutritional security. The role of vegetables as a major source of phytonutraceuticals like vitamins, minerals, antioxidants and fibers are being well recognized in a balanced diet and provide source of income to farmers, seed producers, processors and traders (Sable et al., 2020).

India is the second largest producer of vegetable in the world after China producing around 188 million tonne from just 10.5 
million hectare area. Though pulses are grown in both Kharif and Rabi seasons, Rabi pulses contribute more than 60 per cent of the total production. In India total area under cowpea cultivation is 1.5 million hectare whereas, in Gujarat it is cultivated commercially in an area of 0.5 lakh hectare (Anonymous, 2020).

Cowpea (Vigna unguiculata (L.) Walp.), $2 n=2 x=22$ belongs to family Fabaceae, popularly known as chauli is an important legume vegetable crop. It is grown in tropics for its tender green pods and shelled immature seeds used as vegetable and dry seeds used as pulse. It is grown for immature pods and mature grains.

The haulms are also fed to livestock. Cowpea is known as drought hardy nature, its wide and droopy leaves keeps soils and soil moisture conserved due to shading effect.

It is also known as black-eyed pea or southern pea etc. and has multiple uses like food, feed, forage, fodder, green manuring and vegetable (Saravaiya et al., 2014).

Though, the PGRs have great potential, its application and accurate assessments etc. have to be judiciously planned in terms of optimal concentration, stage of application, species specificity and seasons.

In their wide spectrum of effectiveness on every aspect of plant growth, even a modest increase of 10-15 per cent could bring about an increment in the gross annual productivity by $10-15 \mathrm{t} \mathrm{ha}^{-1}$ (Sharma and Lashkari, 2009).

These synthetic PGRs are put into several uses in horticulture, one of them is to increase crop yield and improve quality. The growth behavior of many plants could be modified or controlled by applying small amount of plant growth regulators, either by seed soaking, root dipping or whole plant spray.
Among several growth substances, gibberellins and auxins are very promising and these are being used on large scale in number of vegetable crops.

The growth promoters like NAA and 2,4-D enhance the source-sink relationship and modified translocation of photosynthates, which will help in better retention of flowers and fruits and seed filling at the later stages of crop growth. The influence of CCC on the leaf colour can be seen shortly after application.

The change in colour is due to a higher chlorophyll-synthesis. To achieve optimum vegetative growth and better translocation of phytosynthates in developing pods, the use of growth regulators appears to be an excellent tool which regulate plant growth and finally alter the plant architecture and yield improvement.

However, very rare information is available on this aspect; therefore, the aim of the present study was to investigate the response of foliar application of PGRs on growth, yield and quality of vegetable cowpea.

Hence, the research study entitled "Effect of PGRs on Quality and Yield Traits of vegetable cowpea [Vigna unguiculata (L.) Walp.]" using cultivar 'AVCP 1' was carried out at Vegetable Research Farm, Regional Horticultural Research Station, ASPEE College of Horticulture and Forestry, Navsari Agricultural University, Navsari with the following objectives:

To evaluate the effect of foliar application of PGRs viz., NAA, PCPA, 2,4-D and CCC on quality parameters of vegetable cowpea

Application of PGRs viz., NAA, PCPA, 2,4-D and $\mathrm{CCC}$ on yield parameters of vegetable cowpea 


\section{Materials and Methods}

A field experiment entitled "Effect of PGRs on Quality and Yield Traits of vegetable cowpea [Vigna unguiculata (L.) Walp.]" was laid out on cowpea during 2020 at Vegetable Research Farm, Regional Horticultural Research Station, ASPEE College of Horticulture and Forestry, Navsari Agricultural University, Navsari.

According to agro-climatic conditions of Gujarat state, Navsari falls under 'South Gujarat Heavy Rainfall Zone, AES-III'. The climate of this zone is typically tropical and monsoonic. An average rainfall of the tract is about $1500 \mathrm{~mm}$ and is normally receive by second fortnight of June and cease by September end.

There were thirteen treatment viz. $\mathrm{T}_{1}$ : Control (No spray), $\mathrm{T}_{2}$ : NAA $10 \mathrm{mg} \mathrm{l}^{-1}, \mathrm{~T}_{3}$ : NAA 15 $\mathrm{mg} \mathrm{l}^{-1}, \mathrm{~T}_{4}$ : NAA $20 \mathrm{mg} \mathrm{l}^{-1}, \mathrm{~T}_{5}$ : PCPA $10 \mathrm{mg}$ $\mathrm{l}^{-1}, \mathrm{~T}_{6}$ : PCPA $15 \mathrm{mg} \mathrm{l}^{-1}, \mathrm{~T}_{7}$ : PCPA $20 \mathrm{mg} \mathrm{l}^{-1}$, $\mathrm{T}_{8}: 2,4-\mathrm{D} 0.5 \mathrm{mg} \mathrm{l}^{-1}, \mathrm{~T}_{9}: 2,4-\mathrm{D} 1.0 \mathrm{mg} \mathrm{l}^{-1}, \mathrm{~T}_{10}$ : 2,4-D $1.5 \mathrm{mg} \mathrm{l}^{-1}, \mathrm{~T}_{11}$ : CCC $200 \mu \mathrm{ll}^{-1}, \mathrm{~T}_{12}$ : CCC $300 \mu \mathrm{l}^{-1}$ and $\mathrm{T}_{13}: \operatorname{CCC} 400 \mu \mathrm{l}^{-1}$.

Observations were recorded for different parameters. The protein content was estimated by Lowry's method as described by Sadasivam and Munickam (1991).

Moisture content was determined by oven drying the pod. The crude fibre content from pulp of cowpea immature green pods. The percentage of TSS content in the cowpea green pods of different treatments was recorded with the help of Erma made hand refractometer (range of 0 to 32).

The pulp was extracted through muslin cloth on refractometer prism and three readings were recorded and expressed in terms of percentage. Chlorophyll content of fresh leaf and pod samples of cowpea was determined by using method as described by Sadasivam and Manickam (1996).

\section{Results and Discussion}

\section{Influence on quality parameters}

Quality parameters viz., chlorophyll content of leaf at second and sixth picking and chlorophyll content of pod at second and sixth picking were significantly influenced by the foliar application of PGRs. Whereas Protein content of immature seed (\%), moisture content of pod (\%), crude fibre (\%) and TSS $\left({ }^{\circ} \mathrm{B}\right)$ were found non-significant.

CCC $300 \mu \mathrm{l}^{-1}$ found best and recorded maximum chlorophyll content of leaf at second (1676.22 mg $\left.100 \mathrm{~g}^{-1}\right)$ and sixth picking (1656.18 mg $100 \mathrm{~g} \mathrm{~g}^{-1}$ ) and chlorophyll content

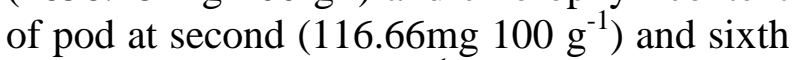
picking (116.34mg $\left.100 \mathrm{~g}^{-1}\right)$.

The application of NAA and CCC at all level increases the chlorophyll content without the modification of leaf anatomy and delayed chlorophyll degradation. Significant increasing in photosynthetic area and high concentration of photosynthetic pigments increases the photosynthesis rate and efficiency which increases the concentration of chlorophyll content in leaves and pods. The delay in leaf senescence could also be attributed to higher chlorophyll content. Shinde and Jadhav (1995) have also reported that the foliar application of NAA significantly increased chlorophyll content in cowpea. Similar trend were also observed by Zewail et al., (2011) in faba bean.

\section{Influence on yield parameters}

Yield parameters viz., marketable pod yield plant $^{-1}(\mathrm{~kg})$ and marketable pod yield $\left(\mathrm{t} \mathrm{ha}^{-1}\right)$ were significantly influenced by the foliar application of PGRs. 
Table.1 Effect of foliar application of PGRs on different traits of cow pea cv. AVCP 1.

\begin{tabular}{|c|c|c|c|c|c|c|}
\hline Treatments & $\begin{array}{l}\text { Protein content } \\
\text { of immature } \\
\text { seed }(\%)\end{array}$ & $\begin{array}{c}\text { Moisture } \\
\text { content of pod } \\
(\%)\end{array}$ & $\begin{array}{l}\text { Crude fibre } \\
\qquad(\%)\end{array}$ & $\begin{array}{l}\text { TSS } \\
\left({ }^{0} \mathrm{~B}\right)\end{array}$ & $\begin{array}{c}\text { Number of } \\
\text { marketable pods } \\
\text { plant }^{-1}\end{array}$ & $\begin{array}{c}\text { Marketable pod } \\
\text { yield } \\
\left(\mathrm{t} \mathrm{ha}^{-1}\right)\end{array}$ \\
\hline $\mathbf{T}_{1}:$ Control & 5.25 & 86.44 & 14.48 & 7.18 & 86.98 & 6.04 \\
\hline $\mathrm{T}_{2}:$ NAA $10 \mathrm{mg} \mathrm{l}^{-1}$ & 5.54 & 85.47 & 13.78 & 7.58 & 93.30 & 9.06 \\
\hline $\mathrm{T}_{3}:$ NAA $15 \mathrm{mg} \mathrm{l}^{-1}$ & 5.83 & 85.04 & 13.47 & 7.68 & 101.45 & 9.56 \\
\hline $\mathrm{T}_{4}:$ NAA $20 \mathrm{mg} \mathrm{l}^{-1}$ & 5.83 & 85.75 & 13.97 & 7.60 & 106.07 & 9.65 \\
\hline $\mathrm{T}_{5}:$ PCPA $10 \mathrm{mg} \mathrm{l}^{-1}$ & 5.54 & 86.64 & 14.12 & 7.53 & 70.68 & 4.93 \\
\hline $\mathrm{T}_{6}:$ PCPA $15 \mathrm{mg} \mathrm{l}^{-1}$ & 5.25 & 87.97 & 13.87 & 7.29 & 70.30 & 4.71 \\
\hline $\mathrm{T}_{7}:$ PCPA $20 \mathrm{mg} \mathrm{l}^{-1}$ & 5.54 & 86.28 & 14.42 & 7.40 & 68.84 & 4.57 \\
\hline $\mathrm{T}_{8}: 2,4-\mathrm{D} 0.5 \mathrm{mg} \mathrm{l}^{-1}$ & 5.25 & 85.28 & 13.65 & 7.27 & 88.87 & 7.17 \\
\hline $\mathrm{T}_{9}: 2,4-\mathrm{D} 1.0 \mathrm{mg} \mathrm{l}^{-1}$ & 5.25 & 85.13 & 14.12 & 7.24 & 92.93 & 7.35 \\
\hline$T_{10}: 2,4-D 1.5 \mathrm{mg} \mathrm{l}^{-1}$ & 5.25 & 84.23 & 14.15 & 7.44 & 96.33 & 8.37 \\
\hline $\mathrm{T}_{11}: \mathrm{CCC} 200 \mu \mathrm{l}^{-1}$ & 5.54 & 84.69 & 13.10 & 7.68 & 103.58 & 10.08 \\
\hline $\mathrm{T}_{12}: \operatorname{CCC~} 300 \mu \mathrm{l}^{-1}$ & 6.13 & 83.59 & 13.00 & 7.77 & 112.93 & 10.44 \\
\hline $\mathrm{T}_{13}: \mathrm{CCC} 400 \mu \mathrm{l}^{-1}$ & 5.83 & 84.54 & 13.08 & 7.70 & 110.98 & 9.79 \\
\hline S.Em. \pm & 0.40 & 1.04 & 0.37 & 0.14 & 3.73 & 0.55 \\
\hline C.D. at $5 \%$ & NS & NS & NS & NS & 10.89 & 1.61 \\
\hline
\end{tabular}


Table.2 Effect of foliar application of PGRs on Chlorophyll content of leaf and pod of cow pea cv. AVCP 1.

\begin{tabular}{|c|c|c|c|c|}
\hline Treatments & $\begin{array}{l}\text { Chlorophyll } \\
\text { content of leaf at } \\
\text { second picking } \\
\left(\mathrm{mg} 100 \mathrm{~g}^{-1}\right)\end{array}$ & $\begin{array}{l}\text { Chlorophyll } \\
\text { content of leaf at } \\
\text { sixth picking } \\
\left(\mathrm{mg} 100 \mathrm{~g}^{-1}\right)\end{array}$ & $\begin{array}{l}\text { Chlorophyll content } \\
\text { of pod at second } \\
\text { picking }\left(\mathrm{mg} 100 \mathrm{~g}^{-1}\right)\end{array}$ & $\begin{array}{l}\text { Chlorophyll content of } \\
\text { pod at sixth picking } \\
\left(\mathbf{m g} 100 \mathrm{~g}^{-1}\right)\end{array}$ \\
\hline $\mathrm{T}_{1}$ : Control & 1425.92 & 1408.97 & 97.58 & 95.84 \\
\hline$T_{2}:$ NAA $10 \mathrm{mg} \mathrm{l}^{-1}$ & 1560.56 & 1586.92 & 113.59 & 111.82 \\
\hline $\mathrm{T}_{3}:$ NAA $15 \mathrm{mg} \mathrm{l}^{-1}$ & 1631.30 & 1594.81 & 114.31 & 112.92 \\
\hline $\mathrm{T}_{4}: \mathrm{NAA} 20 \mathrm{mg} \mathrm{l}^{-1}$ & 1635.22 & 1600.14 & 115.00 & 114.11 \\
\hline $\mathrm{T}_{5}:$ PCPA $10 \mathrm{mg} \mathrm{l}^{-1}$ & 1441.39 & 1442.37 & 104.59 & 102.35 \\
\hline $\mathrm{T}_{6}:$ PCPA $15 \mathrm{mg} \mathrm{l}^{-1}$ & 1444.64 & 1441.32 & 103.95 & 106.07 \\
\hline $\mathrm{T}_{7}:$ PCPA $20 \mathrm{mg} \mathrm{l}^{-1}$ & 1442.13 & 1418.91 & 103.71 & 101.79 \\
\hline $\mathrm{T}_{8}: 2,4-\mathrm{D} 0.5 \mathrm{mg} \mathrm{l}^{-1}$ & 1498.82 & 1456.85 & 108.73 & 109.90 \\
\hline $\mathrm{T}_{9}: 2,4-\mathrm{D} 1.0 \mathrm{mg} \mathrm{l}^{-1}$ & 1533.08 & 1486.53 & 108.78 & 110.17 \\
\hline $\mathrm{T}_{10}: 2,4-\mathrm{D} 1.5 \mathrm{mg} \mathrm{l}^{-1}$ & 1553.28 & 1499.35 & 111.77 & 112.96 \\
\hline $\mathrm{T}_{11}: \operatorname{CCC~} 200 \mu \mathrm{l} \mathrm{l}^{-1}$ & 1602.32 & 1586.35 & 115.39 & 114.85 \\
\hline$T_{12}: \operatorname{CCC~} 300 \mu l l^{-1}$ & 1676.22 & 1656.18 & 116.66 & 116.34 \\
\hline $\mathrm{T}_{13}: \mathrm{CCC} 400 \mu \mathrm{l} \mathrm{l}^{-1}$ & 1665.08 & 1611.03 & 115.90 & 115.33 \\
\hline S.Em. \pm & 21.27 & 38.50 & 3.00 & 3.25 \\
\hline C.D. at $5 \%$ & 62.06 & 112.36 & 8.75 & 9.48 \\
\hline
\end{tabular}


Table.3 Economics of different treatments (Rs. ha ${ }^{-1}$ )

\begin{tabular}{|c|c|c|c|c|c|c|c|}
\hline Treatments & $\begin{array}{c}\text { Pod yield } \\
\left(\mathrm{t} \mathrm{ha}^{-1}\right)\end{array}$ & $\begin{array}{c}\text { Treatment } \\
\text { Cost }\end{array}$ & $\begin{array}{c}\text { Operational } \\
\text { Cost }\end{array}$ & $\begin{array}{c}\text { Total } \\
\text { Cost }\end{array}$ & $\begin{array}{l}\text { Gross } \\
\text { Return }\end{array}$ & $\begin{array}{c}\text { Net } \\
\text { Return }\end{array}$ & B:CR \\
\hline $\mathbf{T}_{1}:$ Control & 6.04 & 0 & 76765 & 88090 & 181200 & 93110 & 1.1 \\
\hline $\mathrm{T}_{2}:$ NAA $10 \mathrm{mg} \mathrm{l}^{-1}$ & 9.06 & 396 & 76765 & 94148 & 271800 & 177652 & 1.9 \\
\hline $\mathrm{T}_{3}:$ NAA $15 \mathrm{mg} \mathrm{l}^{-1}$ & 9.56 & 440 & 76765 & 95130 & 286800 & 191670 & 2.0 \\
\hline $\mathrm{T}_{4}:$ NAA $20 \mathrm{mg} \mathrm{l}^{-1}$ & 9.65 & 484 & 76765 & 95343 & 289500 & 194157 & 2.0 \\
\hline $\mathrm{T}_{5}:$ PCPA $10 \mathrm{mg} \mathrm{l}^{-1}$ & 4.93 & 344 & 76765 & 86353 & 147900 & 61547 & 0.7 \\
\hline $\mathrm{T}_{6}:$ PCPA $15 \mathrm{mg} \mathrm{l}^{-1}$ & 4.71 & 362 & 76765 & 85958 & 141300 & 55342 & 0.6 \\
\hline $\mathrm{T}_{7}:$ PCPA $20 \mathrm{mg} \mathrm{l}^{-1}$ & 4.57 & 380 & 76765 & 85714 & 137100 & 51386 & 0.6 \\
\hline $\mathrm{T}_{8}: 2,4-\mathrm{D} 0.5 \mathrm{mg} \mathrm{l}^{-1}$ & 7.17 & 310 & 76765 & 90518 & 215100 & 124582 & 1.4 \\
\hline $\mathrm{T}_{9}: 2,4-\mathrm{D} 1.0 \mathrm{mg} \mathrm{l}^{-1}$ & 7.35 & 311 & 76765 & 90857 & 220500 & 129643 & 1.4 \\
\hline $\mathrm{T}_{10}: 2,4-\mathrm{D} 1.5 \mathrm{mg} \mathrm{l}^{-1}$ & 8.37 & 312 & 76765 & 92770 & 251100 & 158330 & 1.7 \\
\hline $\mathrm{T}_{11}: \mathrm{CCC} 200 \mu \mathrm{ll}^{-1}$ & 10.08 & 375 & 76765 & 96040 & 302400 & 206360 & 2.1 \\
\hline $\mathrm{T}_{12}: \operatorname{CCC~} 300 \mu \mathrm{ll}^{-1}$ & 10.44 & 419 & 76765 & 96759 & 313200 & 216441 & 2.2 \\
\hline $\mathrm{T}_{13}: \mathrm{CCC} 400 \mu \mathrm{I} \mathrm{I}^{-1}$ & 9.79 & 442 & 76765 & 95563 & 293700 & 198137 & 2.1 \\
\hline
\end{tabular}


Fig.1 Effect of different treatments on chlorophyll content of leaf at second and sixth picking ( $\mathrm{mg} 100 \mathrm{~g}^{-1}$ ) of vegetable cowpea cv. AVCP 1

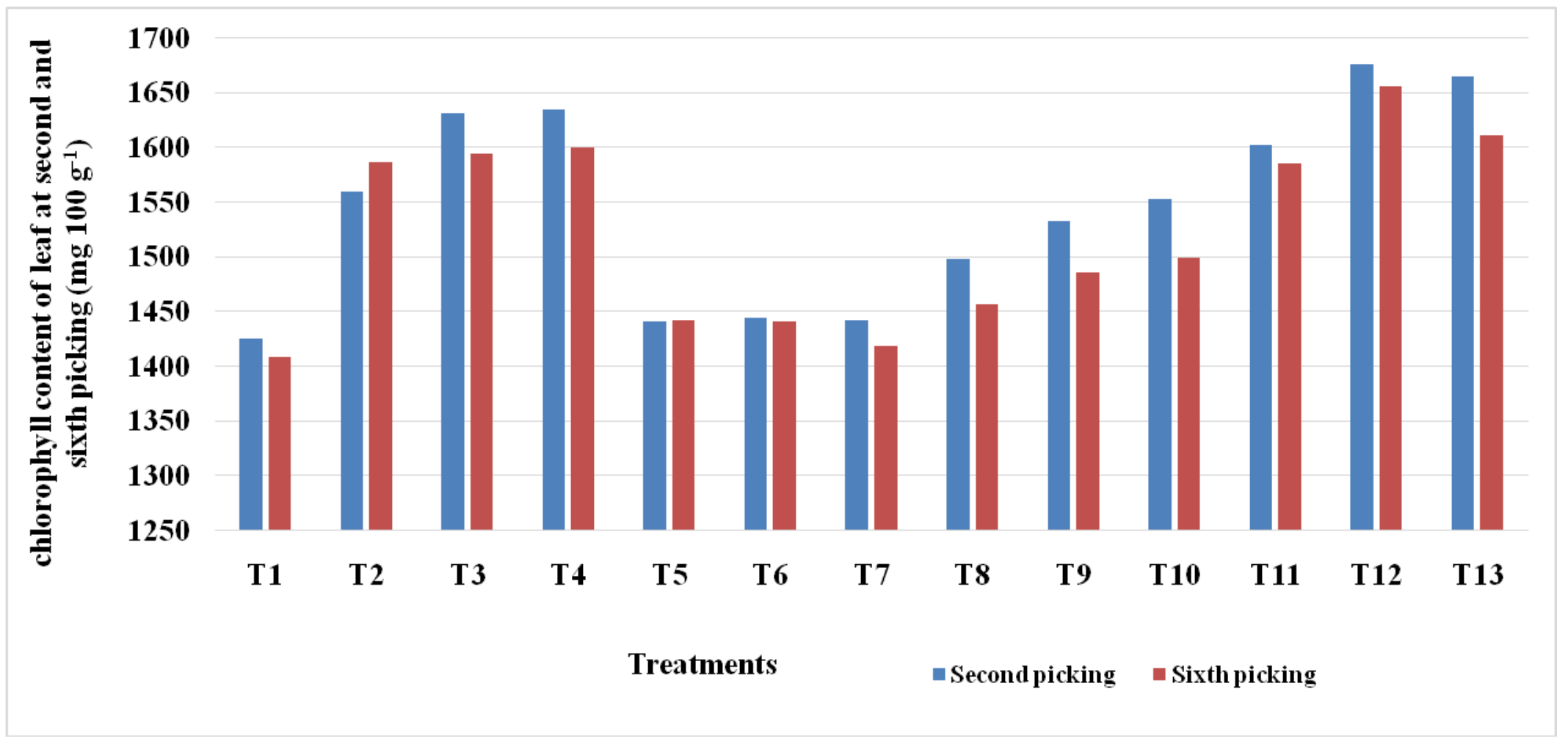


Fig.2 Effect of different treatments on chlorophyll content of pod at second and sixth picking (mg $100 \mathrm{~g}^{-1}$ ) of vegetable cowpea $\mathrm{cv}$. AVCP 1

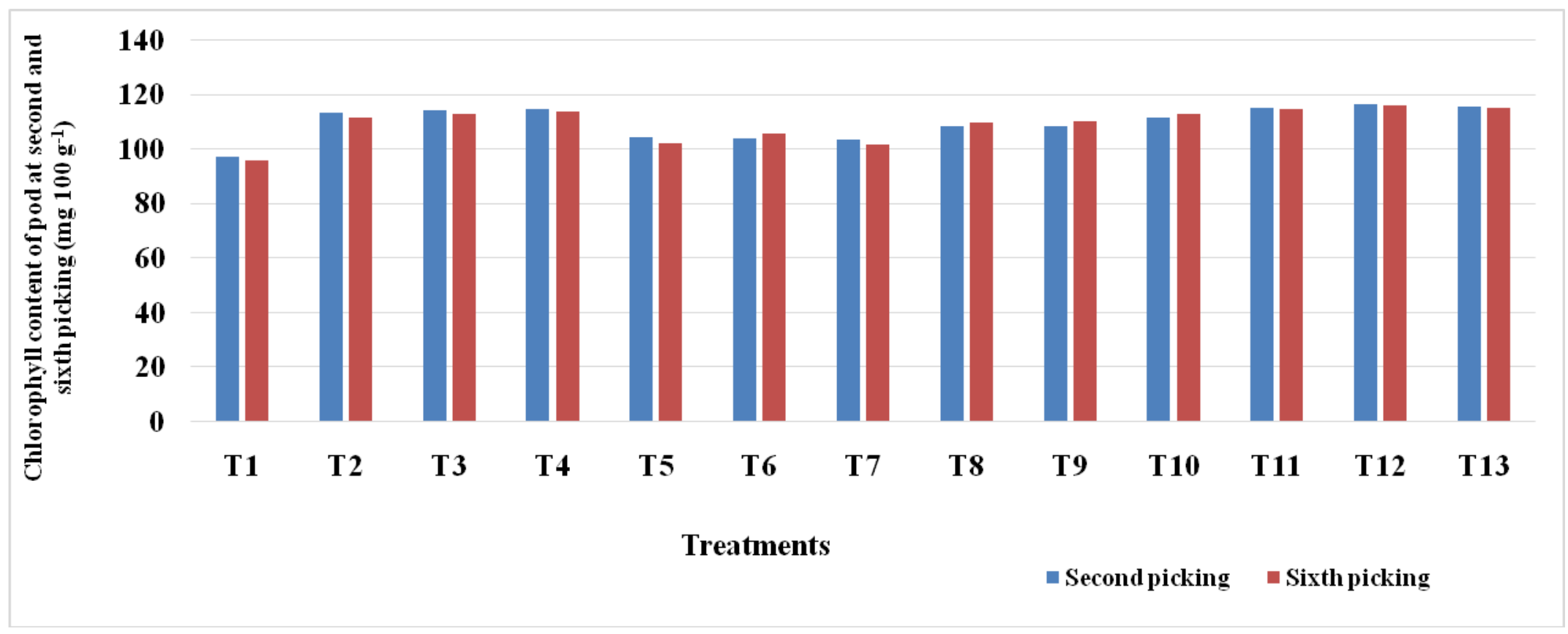


CCC $300 \mu \mathrm{ll}^{-1}$ found best and recorded maximum marketable pod yield plant ${ }^{-1}(0.160$ $\mathrm{kg})$ and marketable pod yield $\left(\mathrm{t} \mathrm{ha}^{-1}\right)(10.44$ ton). Increased yields in these treatments can be explained based on the enhanced vegetative growth, increased fruit sizes and higher fruit numbers.

Exogenous application of plant growth regulators might be causes a greater accumulation of carbohydrates owing to photosynthesis which accelerate the overall growth of plant result in more number of pods and increase size of seeds ultimately more yield with good quality. In particular, all concentrations of NAA and CCC showed increased fruit numbers and per plant yield, which may be because of a reduction in flower drop and fruit abortion thereby bring about an improvement in yield potential. Similar results were also found by Resmi and Gopalakrishnan (2004) in yard long bean; Sharma and Lashkari (2009) in cluster bean; Kumar et al., (2003) in chickpea; Das and Prasad (2003) in mung bean; Desai and Deore (1985) in cowpea and Patil et al., (2005) in green gram.

\section{Influence on Economics}

CCC $300 \mu 1^{-1}$ registered the highest net profit $2,16,441$ Rs. ha ${ }^{-1}$ with B:CR value of 2.2 as compared to rest of the treatment, followed by $\mathrm{T}_{11}$ (B:CR of 2.1). Whereas, treatment $\mathrm{T}_{6}$ (PCPA $15 \mathrm{mg} \mathrm{l}^{-1}$ ) and $\mathrm{T}_{7}$ (PCPA $20 \mathrm{mg} \mathrm{l}^{-1}$ ) recorded the lowest net realization 55,341.85 and 51,386.35 Rs. ha ${ }^{-1}$ respectively, with lowest B:CR value of 0.6.

\section{References}

Anonymous (2020). India produces 22 million tonne of pulses in 2018-19. Agric. Today,March, 18p.

Das, A. and Prasad, R. (2003). Effect of plant growth regulators $\mathrm{CCC}$ and NAA on the growth and yield of summer mungbean. Ann.of Agric. Res., 24 (4):874-879.

Desai, S. N. and Deore, D. D. (1985). Influence of growth regulators on the seed production of cowpea. $J$. Maharahstra Agric. Uni., 10 (1):89-90.

Kumar, N., Khangarot, S. S. and Meena, R. P. (2003). Effect of sulphur and plant growth regulators on yield and quality parameters of chick pea (Cicer arietinum L.). Ann.Agric. Res. New Series. 24 (2): 434- 436.

Patil, S. N., Patil, R. B. and Suryawanshi, Y. B. (2005). Effect of foliar application of plantgrowth regulators and nutrients on seed yield and quality attributes of mungbean (Vigna radiata (L.) Wilczek.). Seed Res., 33 (2): 142-145.

Resmi, R. and Gopalakrishnan, T. R. (2004). Effect of plant growth regulators on the performance of yard long bean (Vigna unguiculata var.sesquipedalis(L.) Verdcourt). Kerala J. Trop.Agric., 42 (1-2): 55-57.

Sable, P. A.; Saravaiya, S. N. and Sharma Ankur (2020). "Vegetable Crops: Package of Practices", Narendra Publishing House, Delhi, India, 623 p.

Sadasivam, S. and Manickam, A. (1996). "Biochemical Methods" ( $2^{\text {nd }}$ edn.), New Age International Publishers, New Delhi, India, pp: 1-256.

Saravaiya, S. N.; Pandya, H. V.; Chaudhari, K. N.; Patel, G. D. and Kumar, S. (2014). Unaluanechomasurutuno katholvargnoagatyanopak, Choli; Krishigovidhya,67 (1): 8-14.

Sharma, S. J. and Lashkari, C. O. (2009). Response of Gibberellicacid and Cycocel on growth and yield of Cluster bean (Cyamopsistetragonoloba L.) cv. 'PusaNavbahar'. Asian J. Hort., 4 (1): 89-90.

Shinde, A. K. and Jadhav, B. B. (1995). Influence of NAA, ethrel and $\mathrm{KNO}_{3}$ on leaf physiology and yield of cowpea. 
Ann. Pl. Physiol., 9 (1): 43-46.

Zewail, R. M. Y.; Khder, Z. M. A. and Mady, M. A. (2011). Effect of potassium, some antioxidants, phosphoric acid and naphthalene acetic acid (NAA) on growth and productivity of faba bean plants (Faba vulgaris). Ann. Agric. Sci.,49 (1): 53-64.

\section{How to cite this article:}

Sarvaiya, J. P., S. N. Saravaiya, H. S. Patel and Tandel, Y. N. 2021. Effect of PGRs on Quality and Yield Traits of Vegetable Cowpea [Vigna unguiculata (L.) Walp.]. Int.J.Curr.Microbiol.App.Sci. 10(07): 283-292. doi: https://doi.org/10.20546/ijcmas.2021.1007.030 